\title{
The Cenozoic Song Hong and Beibuwan Basins, Vietnam
}

\author{
Michael B.W. Fyhn, Henrik I. Petersen, Lars Henrik Nielsen, Tran C. Giang, Le H. Nga, \\ Nguyen T.M. Hong, Nguyen D. Nguyen and loannis Abatzis
}

The Vietnamese offshore margin holds a substantially underexplored petroleum potential. The key to unravelling this potential lies in understanding the tectono-stratigraphic framework of the region including the Cenozoic mechanisms governing syn-rift and source rock deposition. This is essential for prediction of, for instance the presence and nature of source rocks in South-East Asia and possible reservoir intervals in the syn-rift packages. The Vietnamese part of the Song Hong and Beibuwan Basins (Fig. 1) differs from other basins along the western margin of the South China Sea in that the Palaeogene syn-rift succession is sporadically exposed due to uplift and inversion. These exposures provide a unique glimpse into the Cenozoic syn-rift succession of the basin.

Considerable oil and condensate discoveries have recently been made in the Vietnamese part of the Song Hong Basin. This emphasises the need for improved geological models of the basin in order to unravel the local petroleum systems.

Since 1995, the Geological Survey of Denmark and Greenland and the Vietnam Petroleum Institute have conducted exploration-related, foreign development aid projects in Vietnam funded by the Danish Ministry of Foreign Affairs. The ongoing Danish-Vietnamese research cooperation operates through an ENhanced REsearch CApacity (ENRECA) project. The ENRECA group consists of both Danish and Vietnamese researchers who, through the project, have become the established experts in the region. The ongoing ENRECA work focuses on the geological development of the greater Song Hong Basin (including the Vietnamese part of the Beibuwan Basin). As part of the project activities, the ENRECA group has recently drilled a fully cored well into the syn-rift succession of the basin and is carrying out a comprehensive regional study combining seismic, well and outcrop information.

\section{Evolution of the the Song Hong Basin and the greater Vietnamese margin}

South-East Asia is tectonically one of the most complex regions in the world, shaped by continental collisions and the creation and subduction of oceanic basins. A large portion of the deformation associated with the Indian-Eurasian plate collision was likely accommodated in the neighbouring part of South-East Asia during the Cenozoic (e.g. Leloup et al. 2001). Indochina deformed in response to the collision and may have been squeezed hundreds of kilometres south-east-

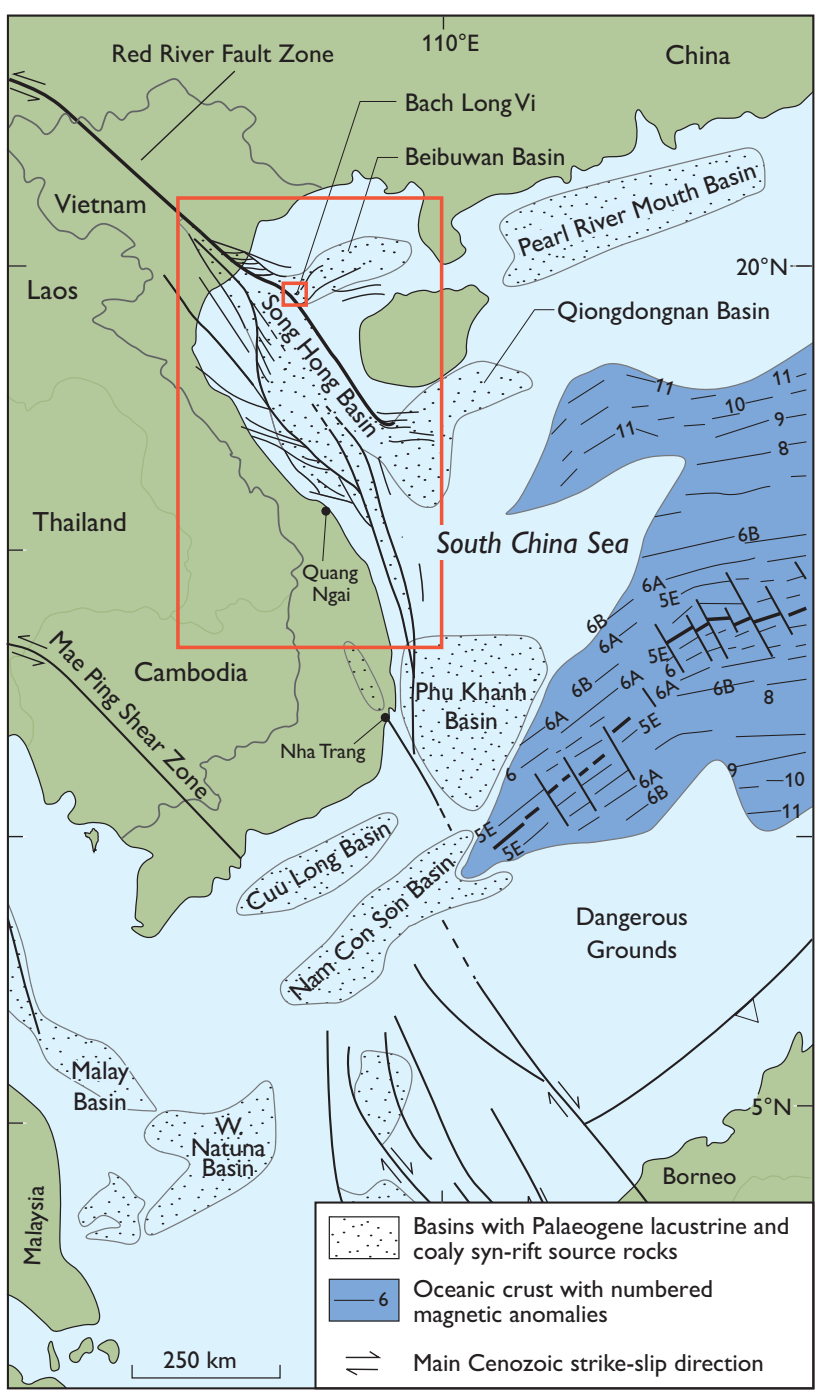

Fig. 1. Map of Indochina and the western part of the South China Sea showing the outline of the main Cenozoic structures and basins with lacustrine and coaly source rocks. The large red rectangle shows the study area, and the small rectangle shows the location of Fig. 3. 
wards from the Himalayan collision front along enormous strike-slip fault zones (Fig. 1).

The Song Hong Basin is the largest Vietnamese sedimentary basin and covers close to one third of the western margin of the South China Sea. Its formation has been attributed to large-scale, left-lateral movements along the Vietnamese mar-

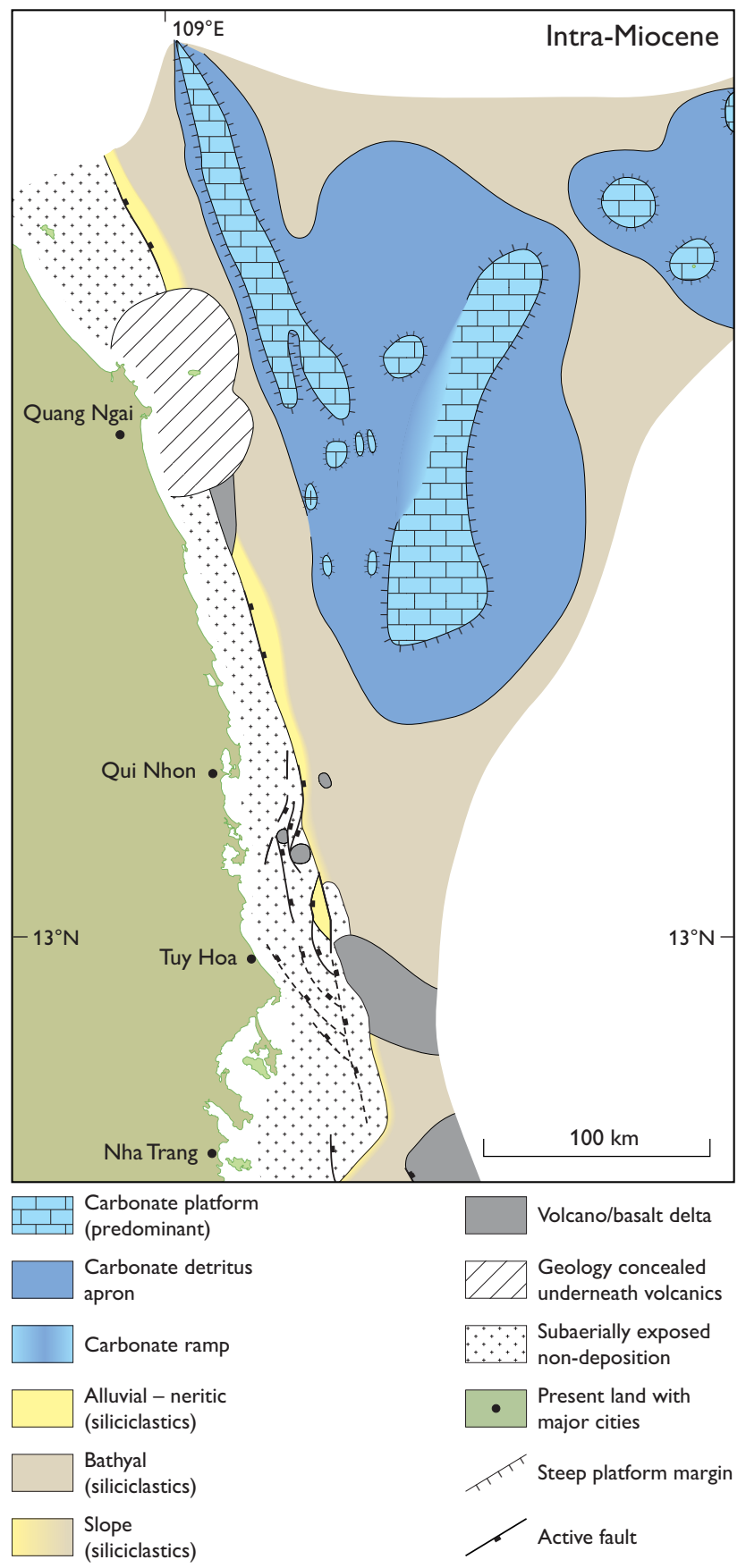

Fig. 2. Intra-Miocene depositional map for the southern part of the Song Hong and the Phu Khanh Basins. Carbonate deposition took place on structural highs, but was affected by siliciclastic input sourced from onshore uplift and local volcanism. gin (e.g. Leloup et al. 2001), whereas a pull-apart model for the basin remains controversial (e.g. Hall \& Morley 2004). Understanding the basic mechanism behind the formation of the Song Hong Basin is crucial for understanding the overall establishment of the western half of the South China Sea. The Song Hong Basin is likely to hold important information on the opening mechanism of the South China Sea.

Whether the greater Vietnamese margin constitutes a transform margin or a more classic oblique rift margin is fundamental to the structural concepts applied when interpreting geophysical data across basins along the margin. So far it has not been possible to evaluate this satisfactorily due to the scarcity of seismic data tied to a limited number of wells offshore Vietnam. However, recent studies of relatively densely spaced seismic profiles tied to wells offshore central and southern Vietnam have led to an increased understanding of the tectonic evolution of the margin (Fyhn et al. 2009). It is clear from these studies that the Song Hong Basin is crucial for reconstructing the overall tectonic development of the western South China Sea.

The current ENRECA study is based on a comprehensive geoscientific database of the Vietnamese portion of the basin and aims to unravel the tectonic and depositional evolution of the basin in a regional context. This will allow a detailed stratigraphic understanding of the basin fill and a comprehensive structural analysis of the basin and the adjacent areas.

The Song Hong Basin forms a depocentre in the northwestern part of the South China Sea and is filled with up to $15-20 \mathrm{~km}$ of sediments. Sediment dispersal to the northwestern part of the South China Sea has largely occurred as spill from the Song Hong Basin. The distribution and style of sediments in the surrounding basins are therefore closely linked to the depositional pattern in the Song Hong Basin. Deposition evolved rapidly in the basin and varied in time and space from lacustrine and fluvial to marine sedimentation. Sedimentary environments ranged from carbonate platform, siliciclastic and lava deltas to shelf, slope and basin floor and were subject to relative sea-level changes. Combined with high sedimentation rates this makes the basin well suited for studies of Cenozoic depositional trends along the western South China Sea.

The depositional development in the basin is investigated through seismic stratigraphic and facies analyses, and well data are closely integrated in the analysis in order to extract age and lithologic information. Palaeogeographic reconstructions illustrate the gross-sedimentary evolution of the basin and form a primary result of this part of the study (Fig. 2). Information on the regional geological evolution can be obtained from the depositional style of the basin in addition to information on the establishment of the South 


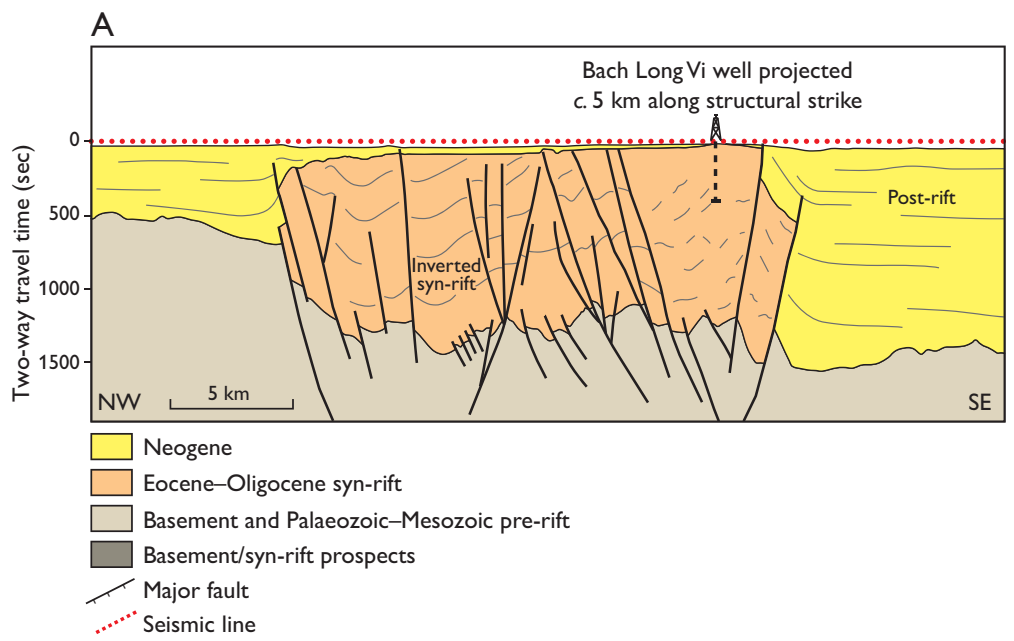

B

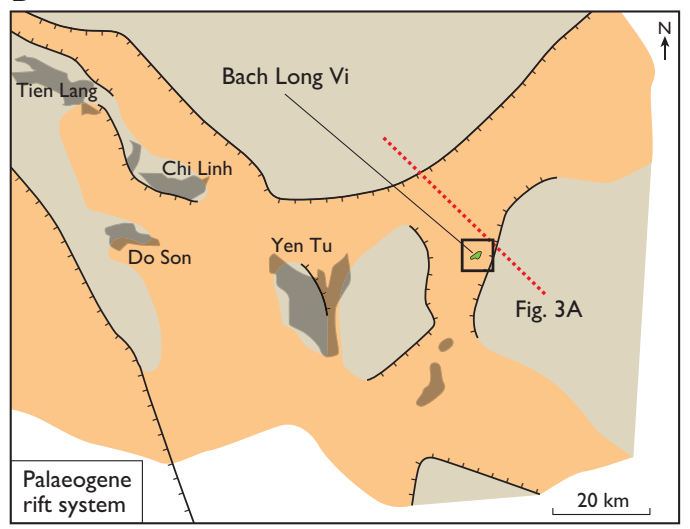

Fig. 3. A: Geotransect across the inverted Palaeogene graben, which is exposed on the island of Bach Long Vi a few kilometres from the profile. The approximate well trajectory is projected onto the section. The transect is based on the seismic line 89-1-103 (partly shown on Fig. 3B, red, dotted line). B: Map showing the outline of the primary Paleogene syn-rift depocentre and syn-rift structural highs in the north-eastern Song Hong Basin. Oil and condensate discoveries in the area are sourced from lacustrine and coaly syn-rift source rocks. Bach Long Vi forms a window to a graben directly linked with the syn-rift kitchen areas of the recent discoveries made in fractured and karstified Palaeozoic carbonates in the area.

China Sea, regional uplift history, sediment transport and Cenozoic climate.

Neogene basalt volcanism affected large parts of the Vietnamese margin from the Nam Con Son Basin in the south to the Song Hong Basin in the north, and acted coeval with widespread carbonate platform growth along the margin (Fig. 2). Magmatism was associated with regional onshore uplift and denudation, which seems to have had a significant derivative effect on contemporary deposition (Fyhn et al. 2009). Increased siliciclastic input to the offshore basins and elevated inorganic nutrient concentrations in platform areas associated with onshore uplift and denudation led to a lowering of long-term carbonate production and deposition. As a result, carbonate platforms drowned and became buried underneath kilometre-thick, prograding siliciclastic sediment wedges during the Late Neogene. In the southern Song Hong Basin, volcanics and carbonate platforms are nicely revealed by seismic data and are drilled and dated in wells (Fig. 2).

\section{Syn-rift and source-rock deposition}

Cretaceous and Cenozoic organic-rich lacustrine mudstones and humic coals, which were deposited during periods of rifting, form world-class source-rock intervals in South-East Asia (Fig.1). These source rocks frequently occur adjacent to coarse-grained, reservoir-quality sedimentary bodies derived from nearby elevated hinterland areas. Moreover, source-rock intervals are often located adjacent to fractured basement or pre-rift successions with effective reservoir characteristics. Understanding these rift systems, including the occurrence and genesis of lake systems and the sedimentary successions capable of generating and storing hydrocarbons, is critical when evaluating local petroleum systems over larger parts of South-East Asia.

It has long been recognised that stratigraphic wells through syn-rift successions are useful to unravel the deeper depositional systems including source-rock units (e.g. Sladen 1997). This is particularly true offshore northern Vietnam, where syn-rift lacustrine and coaly-sourced petroleum mainly occur in fractured and karstified pre-rift carbonates. Even so, little is known about the source-rock system, and deep wells drilled into the syn-rift succession have not provided information on the source rocks of the area. To address this problem, the ENRECA group drilled a $500 \mathrm{~m}$ fully cored well into the inverted syn-rift succession on the island of Bach Long Vi (Figs 1, 3) where highly oil-prone source-rock intervals are widespread. The core demonstrates a thick lacustrine succession within the area. At the time of writing, cores are transported to a core depository to be analysed in detail. Bach Long Vi has low relief and dense vegetation, and hence well-exposed outcrops on the island are limited to locations along the shore, and a satisfactory study of syn-rift sedimentation and source-rock quality is not possible based on outcrops alone. However, combined with the cored stratigraphic well, the geology of Bach Long Vi provides a unique opportunity to study syn-rift deposition and source-rock composition. The core provides a regional type section of 


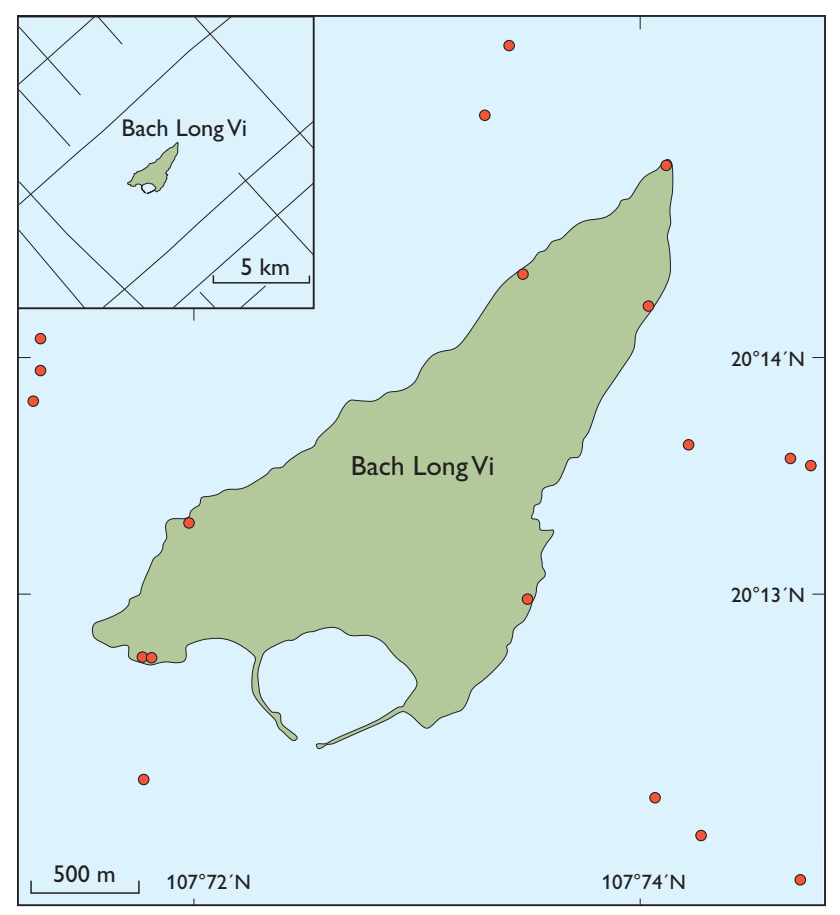

Fig. 4. Map of the island of Bach Long Vi. Red dots show sites of sourcerock samples. The inset map shows the nearest industrial seismic lines in the area. For location see Figs 1 and 3.

the Palaeogene syn-rift succession. Sampled source-rock intervals are studied through general source rock screening and biomarker analysis combined with more advanced analysis of selected source-rock intervals.

Situated at the intersection of the Beibuwan and the Song Hong Basin, Bach Long Vi occurs in the centre of a newly discovered petroleum province offshore Vietnam (Fig. 3). Bach Long Vi sits at the top of a prominent structure associated with inversion of a Palaeogene graben. The island therefore provides a window into the nature of the Palaeogene syn-rift succession of the area. Highly oil-prone lacustrine mudstones with an organic content ranging from $c .2$ to 7 wt.\% total organic carbon were sampled from scattered outcrops on Bach Long Vi and from sub-sea outcrops around the island (Fig. 4). ENRECA analyses of these excellent source rocks confirm that petroleum-prone mudstones occur at various stratigraphic levels that crop out over the entire area (e.g. Petersen et al. 2004 and new unpublished data).
A dense net of seismic data cover the area offshore Bach Long $\mathrm{Vi}$ and reveals a $\mathrm{N}-\mathrm{S}$ to $\mathrm{NE}-\mathrm{SW}$-trending, inverted Eocene-Oligocene graben. The graben fill sub-crops at and closely beneath the seafloor and forms the core of Bach Long $\mathrm{Vi}$ (Fig. 3A). The graben is part of a larger rift system that actively subsided during Palaeogene time (Fig. 3B). The deposits, including the sampled source rocks on and around Bach Long Vi, therefore form part of a regional syn-rift system, which is directly continuous with the syn-rift kitchen areas sourcing the recent oil and condensate discoveries in the region (Fig. 3). The preliminary results suggest that rich source-rock intervals could be present throughout much of the syn-rift succession in the basin, highly encouraging for further exploration.

\section{Acknowledgements}

The ENRECA project is funded by the Danish Ministry of Foreign Affairs via Danida. PetroVietnam co-funded the ENRECA 3 well and is thanked for providing data and for permitting publication of this paper.

\section{References}

Fyhn, M.B.W., Boldreel, L.O. \& Nielsen, L.H. 2009: Geological development of the central and south Vietnamese margin: Implications for the establishment of the South China Sea, Indochinese escape tectonics and Cenozoic volcanism. Tectonophysics 478, 184-214.

Hall, R. \& Morley, C.K. 2004: Sundaland Basins. In: Clift, P. et al. (eds): Continent-ocean interactions within the East Asian marginal seas. Geophysical Monograph Series 149, 55-85. Washington D.C.: American Geophysical Union.Leloup, P.H., Arnaud, N., Lacassin, R., Kienast, J.R., Harrison, T.M., Trong, T.T.P., Replumaz, A. \& Tapponnier, P. 2001: New constraints on the structure, thermochronology and timing of the Ailao Shan-Red River shear zone, SE Asia. Journal of Geophysical Research 106, B4, 6683-6732.

Petersen, H.I., Nytoft, H.P. \& Nielsen, L.H. 2004: Characterisation of oil and potential source rocks in the northeastern Song Hong Basin, Vietnam: indications of a lacustrine-coal sourced petroleum system. Organic Geochemistry 35, 493-515.

Sladen, C. 1997: Exploring the lake basins of east and Southeast Asia. In: Fraser, A.J., Matthews, S.J. \& Murphy, R.W. (eds): Petroleum geology of Southeast Asia. Geological Society Special Publications (London) 126, 49-76.

\footnotetext{
Authors' addresses

M.B.W.F., H.I.P., L.H.N. \& I.A., Geological Survey of Denmark and Greenland, Øster Voldgade 10, DK-1350 Copenhagen K, Denmark.

E-mail:mbwf@geus.dk

T.C.G. \& L.H.Ng., Vietnam Petroleum Institute, 173 Trung Kinh Str., Yen Hoa Wrd., Cau Giay Dist., Hanoi, Vietnam.

N.T.M.H., Hanoi University of Mining and Geology, Dong Ngac, Tu Liem, Hanoi, Vietnam.

N.D.N., Hanoi University of Science, 334 Nguyen Trai-Thanh Xuan-Hanoi, Vietnam.
} 